\title{
The Effect of Implementing the Rules of Corporate Governance on the Accounting Disclosure for Insurance Companies listed in Amman Stock Exchange: Empirical Study
}

\author{
Sarhan Hawary ${ }^{(1)}$ Hamza Alaodat ${ }^{(2)} \cdot$ Ahmad Elkhateeb $^{(3)}$ \\ Alhussien Bin Talal University \\ Department of Accounting and Financial Sciences
}

\begin{abstract}
This study aimed to identify the impact of applying the rules of corporate governance on accounting disclosure in the financial reports in Jordanian insurance companies. Therefore, the concept of corporate governance and its rules have been dealt with, as well as the effect of the accounting disclosure on financial reports. This study used the analytical descriptive method through collecting the data by developing a questionnaire distributed over the study sample of (14) insurance companies, (53) questionnaire were distributed to identify the constituent of the board of directors sample and executives members and divisions heads. Statistical Analysis (SPSS) program has been used to analyze the data and to test hypotheses. The study has reached a range of outcomes, including: The existence of an arbitrator and effective basis for the rules of corporate governance, but still needs further development and follow-up. There are some laws that contribute to the protection of shareholders and investors in insurance companies and show that there is an application of the elements of fair and equal treatment of all investors. The study revealed the lack of sufficient elements of disclosure and transparency for all stakeholders' interests in insurance companies, which could reflect negatively on the decisions of investors and decision makers. Furthermore, results show that there are limitations in the role of boards of directors in the selection of executives which reflects a direct impact on decision-making. The study recommends the need to exert more efforts and follow developments concerning the application of governance rules by holding training programs to reflect the concepts of the application of governance rules and must work to expand the powers of the stakeholders in the exercise of the supervisory role of the management, and increase the level of disclosure and transparency in financial reporting to provide sufficient security to shareholders
\end{abstract}

Keywords: Corporate Governance, Accounting Disclosure, Insurance Companies.

\section{INTRODUCTION}

The concept of corporate governance has been linked to globalization, economic collapses and financial crises that occurred throughout the world as a consequence of weak legislation and laws and risk management ineffectiveness.

The interest in governance has increased after the widespread of significant investments which require the separation between investors who are the stakeholders and those who manage such investments and companies. Thus, it has been necessary to have laws to organize the relationship between parties involved, (Manaseer, 2013). Consequently, governance has become one of the important topics that can be applied to private as well as public companies, as a result of governance trust was lost in money markets, and the mistrust in accounting information in financial lists, also auditors' manipulation in accountancy and financial lists disclosures, furthermore, trust in financial reports have been lost too (Abu Hamam, 2009) This implied that stakeholders want so much the corporate governance to be applied in their companies and investments.

International organizations have started to adopt governance and applied in their institutions such as International Money Fund, International Bank and the Economic and Development Cooperation Organization which in 1999 issued the principles of corporate governance. Such principles consist of The availability of effective governance framework, the protection of shareholders rights, disclosure and transparency of accounting information, shareholders fair treatment, Board of directors' responsibility and the role of stakeholders. All of these principles aim at controlling and directing managerial and financials respect of disciplines and planned policies, increase competition's ability and corruption encounter. (Seham \& Faraj, 2012)

Corporate governance is considered to be one of the effective instruments by which investments are attracted, securities exchange market is activated and, the economic development process effectively enhanced, through the application of the governance principles, the accountancy processing would be under control, as well as the control of the shape and width of financial lists/ content. All of these will work on achieving accounting information disclosure and transparency which reflects on organizations performance development. The current study seeks identification of the impact of governance rules application on accounting disclosure, then, to clarify the importance of governance rules application on the effect on disclosure and transparency of financial reports, and reveal difficulties that hinder or decrease these rules' implementation. 
The problem and Questions of the Study

The aforementioned showed the importance of implementing governance rules on effecting the level of disclosure and transparency on financial reports, thus the problem of the study lays on the answering of the following major question:

What is the impact of implementing governance rules on accounting disclosure in financial reports of insurance companies listed in Amman Exchange?

Sub-questions stem from this major question as follow:

1- What is the effect of a solid and effective foundation of corporate governance availability on accounting disclosure in financial reports of insurance companies listed on Amman Stock Exchange?

2- What is the impact of implementing the rule of protection of shareholders and investors availability on accounting disclosure in financial reports of insurance companies listed on Amman Stock Exchange?

3- What is the impact of implementing the rule (equal and fair treatment among all shareholders) on the accounting disclosure in financial reports of insurance companies listed in Amman Stock Exchange?

4- What is the impact of implementing the rule (the role of stakeholders) in control exercising on accounting disclosure in financial reports of insurance companies listed in Amman Stock Exchange?

5- What is the impact of implementing the rule (disclosure and transparency)?

6- What is the impact of implementing the rule (Board of directors' responsibility) in control exercise over management, and its role in enhancing accounting disclosure in financial reports of insurance companies listed in Amman Stock Exchange?

\section{The Importance of the Study}

The importance of this study stems from revealing the significant and appropriate role to encourage the implementation of governance rules in insurance companies listed in Amman stock exchange due the importance of this stock market, and to its significance in the development and rejuvenation of the Jordanian economy which requires the availability of trust and accounting disclosure for all investors and shareholders. The implementation of companies governance is considered one of the fundamentals that must abide by all companies listed in Amman Stock Exchange due to its positive effects on the complete accounting disclosure process and all parties who use companies' disclosures as financial reports.. In addition, companies' managers benefit from this study's results, also encourage them to implement governance rules.

The importance of this study stems also from the importance of the topic it examines, whereas, this study is considered to be a pioneer study- to the best of researcher's knowledge- that discusses corporate governance and implementation on the Jordanian insurance companies
Objectives of the Study

This study aims at achieving the following objectives:

1- Identifying the concept of governance and the positives from corporate governance, reveal the importance of its implementation and its impact on accounting disclosure.

2- Measuring the impact of corporate governance rules implementation at accounting disclosure's level among the Jordanian insurance companies.

3- Provide recommendations and suggestions which may lead to help in and enhance awareness of governance implementation importance by the Jordanian insurance companies.

Hypotheses of the Study

The following hypotheses are developed while relying on the elements of the study's problem and questions, and as indicated in most of the previous studies regarding corporate governance:

\section{The major hypothesis is}

H1: There is statistically significant impact at $=0.05$ of corporate governance rules' implementation on accounting disclosure of insurance companies listed in Amman stock exchange

Sub-hypotheses:

1 - There is a statistically significant impact at -0.05 for the presence of foundation elements that are solid and effective of governance rules on accounting disclosure enhancement in financial reports of insurance companies listed in Amman stock exchange.

2- There is a statistically significant impact at $(-0.05)$ for the presence of elements of shareholders and investors protection on accounting disclosure enhancement in financial reports of insurance companies listed in Amman stock exchange

3 - There is a statistically significant impact at (-0.05) for the presence of elements of fair and equal treatment among all shareholders on accounting disclosure enhancement in financial reports of insurance companies listed in Amman stock exchange

4- There is a statistically significant impact at $(-0.05)$ for the presence of elements of stakeholders role support in control exercising on management on accounting disclosure enhancement in financial reports of insurance companies listed in Amman stock exchange

5-There is statistically significant impact at $(-0.05)$ for the presence of elements of disclosure and transparency on accounting disclosure enhancement in financial reports of insurance companies listed on Amman stock exchange

6-There is statistically significant impact at $(-0.05)$ for the presence of elements that determine board of directors responsibilities on accounting disclosure enhancement in financial reports of insurance companies listed in Amman stock exchange 
Theoretical Framework and Previous Studies

\section{Corporate Governance Definition}

Is a set of mechanisms that support self-control in the establishment until it makes decisions with which it increases the value of the company for its owners.( Marashdeh,2014) Governance is defined as the followed approach by company's stakeholders in order to control their own interests (Madhani,2015). Also, governance is the method or the system by which the company's management exercises control over it (Gore, et al, 2005) Furthermore governance is defined as ,the approach that secure high competency and effectiveness for company's operations until the company's objectives that shareholders developed be achieved( Al Moatez et al,2013)

In summary, corporate governance is a set of rules, regulations, standards and internal procedures that clarify fairness and balance in the relationship between company's management and other stakeholders and those who deal with the company, whereas such rules serve their interests and provide them with expected needs. It acts as promisefulfilling by the company to stakeholders. This can be achieved through activity directing and control tightening through accountability, transparency and the needed nonpersonal and unbiased subjectivity. The availability all of these leads to economic strength which in turn leads to economic and social enhancement. Consequently, it restricts potential conflict.

\section{Corporate Governance Rules}

Governance rules can be categorized into six sets. Each of these sets branches into groups of principles as it is described by Economic Cooperation and Development Organization (Abu Hamam, 2009):

\section{1- The availability of effective governance framework}

In order to have governance effective framework, it is important to provide complete transparency and clarify responsibilities among relevant parties,. In order to be effective framework it must contain the following:

- It must have an impact on economic performance, market competency and transparency, and incentives which should be available to market participants.

- Rights and responsibilities should be represented in-laws in order to secure trust and provide the best interest to the public.

- Legal governance requirement should be implementable and in accordance with laws

- Supervisory and executive parties must enjoy full authority, required honesty, and sufficient resources so as to be able to perfectly work in terms of accuracy, subjectivity, and necessary competency.

\section{2- THE PROTECTION OF SHAREHOLDER RIGHTS}

Governance rules depend on shareholder rights' protection through the application of controlling devices which provide them several matters such as : voting rights, participation in core changes in the company, voting on decisions are made during the general assembly meetings, ownership rights and provide them withal and sufficient information, and their right to inspect matters subjected to decisions made and to grant them voting right whether they were present or absent, and to have election right, dismissal of board members, rights for dividends distribution and assets' sale or transfer.

\section{3- SHAREHOLDERS' FAIR TREATMENT}

Equality must be for all shareholders, this necessitates confronting all obstacles that may hinder the voting process. Provide protection for the minority against exploitation by bigger shareholders; provide all information to all shareholders prior to purchasing transactions. Equality includes the ban on shares' circulation that lacks disclosure and transparency.

\section{4- STAKEHOLDERS ROLE IN REGARD TO GOVERNANCE REGULATORY RULES}

Corporate governance framework should include stakeholders' rights recognition according to relevant laws, encourage cooperation between companies and stakeholders in wealth generation, work opportunities, existing projects' sustainability achievement on sound financial base. This includes the assurance of stakeholders respects the protection of the law; provide stakeholders with the opportunity to have reimbursements in case their rights should be violated. Furthermore, performance levels enhancement through mechanisms put in place to have stakeholders' participation, provide an opportunity to have information relevant to governance regulatory principles, development and corporate governance explanations.

\section{5- DISCLOSURE AND TRANSPARENCY}

Disclosure should include the following:

- Company's operational and financial results, objectives and goals of the company, majority right and voting right, board members, main CEOs, ranks, salaries incentives and privileges, risk factors, stakeholders' financial issues and corporate governance policies.

- Information review, and be disclosed according to accounting and financial standards.

- Provide authority to the external auditor, via a subjective way in financial lists preparation through annual review by the independent reviewer.

- Enable information users to obtain such information in reasonable time and cost.

\section{6- Responsibilities of Board of Directors}

The boards of directors' responsibilities include the following:

Provide complete information along with the safety of applied rules to achieve company's best interest. Harmony among existing laws should be present. 
Take into consideration all stakeholders' concerns Achieve comfortable treatment to all shareholders.

In addition, the board of directors performs the following duties:

1- Set up goals, follow companies' implementation and performance and capital expenditure supervision, and assets sale and procurement.

2- Assign executive officers and determines their benefits.

3- Board members candidacy should be transparent

4- Follow up on any potential conflict of interest whether at the executive management level, boards of directors and shareholders

5- Be sure of company's accounting and financial reports safety

6- Follow up on corporate governance effectiveness and perform any needed changes.

7- $\quad$ Supervise disclosure process so as to be able to conduct a subjective assessment of company's affairs independent from executive management. Board of directors should be able to access accurate information in needed time.

Previous studies:

Researchers cited the most important and related studies as follow:

Abu Hamam, (2009) aimed in his study to examine the impact of governance rules implementation on accounting disclosure and financial reports quality.

The study discussed the concept of governance, importance, objectives, and rules and the accounting disclosure and financial reports quality implementing impact with governance rules. It clarified the intertwined relationship between researcher used descriptive analytical approaches in the study. Study's sample consists of 150 CEO of companies listed in the securities market in Palestine. The data collection tool was a questionnaire. Data were analyzed via SPSS. Results of the study revealed that: the corporate governance implementation contributed greatly to accounting disclosure and financial report quality enhancement. The increase of governance culture has caused better position for companies to achieve their goals. The study recommends that, it is necessary to have needed elements to ensure governance implementing through the establishment integrated managerial and professional structure.

Sharati (2010) conducted a study that aimed to investigate disclosure measurement of corporate governance in their financial reports. The sample of the study consists of 64 shareholding industrial companies in Jordan for the year 2008. Researcher-developed governance disclosure indicator with 37 item of information relevant to governance. 17 items were mandatory and 20 item optional results showed that the governance mandatory disclosure level was high and close to companies but not complete. There were no statistically significant variations in participated companies' disclosure level. While governance optional disclosure is low and varied among companies. Results revealed also, the presence of a statistically significant positive relationship between governance optional disclosure and the presence of each auditing committee and the separation of CEO and the general manager. Also, there is a statistically significant negative relationship between these disclosures at the number of independent members of the board of directors.

Al Shanaq (2012) conducted a study aimed at determining the level of mandatory disclosure and optional disclosure of corporate governance in annual financial reports of Jordanian commercial banks. Also, to determine the relationship between mandatory disclosure level and the optional disclosure of corporate governance annual financial reports and the financial performance of Jordanian commercial banks during the period of 2008-2011. The sample of the study consists of (13) Jordanian commercial banks, the study used descriptive statistical approach; and multiple aggression analysis to test hypotheses. Results revealed that corporate governance total disclosure of annual financial reports in both parts the mandatory and optional disclosures is high, however, mandatory disclosure was higher than the optional disclosure.

The study recommends the necessity of conducting further academic studies about corporate governance disclosure.

Al Mustafa (2012) study aimed at identifying the practical extent of profit management phenomenon of industrial companies listed in Amman, and examining the impact of corporate governance on profit management of these companies.

The study used statistical descriptive approaches to test the correlation between study's variables. The sample of the study consists of 62 industrial companies which have the needed data.

Results showed participant companies have exercised profit management in different ways during study's period 2010.

The study recommends the importance of profit management; and its negative consequences if it is used for personal interest. Also, it recommends further studies in the field of profit management.

Al Motaz et al (2013) aimed in their study to investigate the relationship between some corporate governance mechanisms, company characteristics and the level of corporate governance disclosure in the kingdom of Saudi Arabia. Furthermore, it aimed at deepening the major motivations of understanding that leads to a reporting and disclosures of corporate governance in one of the developing countries. Researchers relied on financial lists belong to 97 Saudi companies listed in Saudi stock market during the period of 2006-2007, the content of these financial lists was analyzed, while statements were analyzed via multiple regression analysis to achieve the study's objectives.Corporate governance is the dependent variable while company's factors such as: profitability, liquidity, debt volume and the size of the company as independent variables, and some of the corporate governance mechanisms such as the board of directors autonomy, and auditing committee size as independent variables too.

Result also showed that the autonomy of the board of the directors and the size of the review committee, profitability, liquidity and financial leverage are major 
determinants of corporate governance disclosure in Saudi Arabia.

Marashdeh (2014) aimed at his study at identifying the effect of corporate finance on industrial and service companies in Jordan during the period 2000-2010. This study applied agency theory to reveal the relationship between corporate governance and its performance. Whereas this theory is the concern with agency between company's owners and its manager which results in hindering benefit maximizing. Thus, corporate governance mechanisms are effective to solve this problem. Multiple regression panel data analysis was used as the main means in the study's data, also.

Generalized least square (GLS) random effects models as a statistical method to select the impact. The sample of the study consists of 115 company listed on Amman stock exchange. Cooperate governance data which was collected from Ozores base, in addition to companies performance, will be better if the board of directors chief and CEO be united in one person. Also, the non-executive manager has a negative role in the company's performance. This result contradicts the agency theory which proposes the opposite. Furthermore, the result shows the presence of the positive relationship between foreign ownership and company's performance.

Sartawi, (2015) aimed at identifying the impact of corporate governance implementation on companies performance listed in Gulf States Cooperation Council stock exchange. Also to identify the difference degree in corporate governance by the same companies. In order to achieve these objectives, researcher conducted data analysis of published by participants' participated companies were 240 company from financial sector: Banks show the presence of sufficient level of abiding by corporate governance which there is level difference in its implementation of corporate governance, this resented the positive impact on corporation's market value and operational performance.

Through the review of the aforementioned previous studies has revealed difference and variation in their objectives. Some of aim at revealing the effect of corporate governance implementation of corporation listed in stock markets in different implementing country such as Sarlawi, 2015; Marashdeh 2014, while other studies aimed at revealing the effect of corporate governance on profit management practices as Al Mustafa 2012, and others linked the effect of corporate governance implementation and accounting disclosure and financial reports quality (Abu Hamam 2009) and other studies clarified the disclosure level of about corporate governance in financial reports such as Shunaq 2012, Motaz et al 2013, Sharati 2010. it has been noticed that some of these previous studies differ from this study in terms of knowing corporate governance disclosure level, while others come in agreement with this study in terms of the relationship of corporate governance implementation with accounting disclosure. This study is unique by implementing population of insurance companies listed in Amman stock exchange.
The methodology of the study:

1- Data collection sources

a- Primary source: whereas a questionnaire was developed and distributed to skilled participants. Likert scale was used to determine the respondents' agreement degree with each item: Each item was given one degree from five (strongly, disagree, little bit agrees, agree, strongly agree.

There are represented in number such as 5, 4,3,2,1 respectively

The following scale was used for result analysis purpose:

From 1-2.33

From 2.34-3.67 medium

From 3.68-5 high

b- Secondary sources:

Data was obtained them specialized and relevant literature such as books, journals, research, reports, governmental document, laws, and by-laws to cover the theoretical section of the study

\section{2- Population and sample of the study}

-population: consists of insurance companies listed in Amman stock exchange, 28 corporates in total.

-sample: a sample was chosen from population via strata random approach sample members are managers and decision makers in insurance companies participants are 53 managers represent top and middle management. 53 questionnaires were distributed over entire sample respondents. Validity and reliability of questionnaire were obtained. 53 questionnaires were eligible for analysis.

\section{3- Instrument's data analysis}

Several statistical approaches were utilized:

1- Descriptive approaches that include percent, frequency, means and standard deviations for all various items; so as to provide comprehensive agreement description of all participants over various items.

2- $\quad$ Cronbach's Alpha test to assure consistency of measurement tool and consistency. T-Test for hypotheses testing was used

3- $\quad$ ANOVA for variation of means was used.

4- Variables of the study:

1- Independent variables- include corporate governance elements:

A- $\quad$ Solid and effective foundation

B- $\quad$ Factors for state holders and investors protection

C- $\quad$ Fair and equal treatment among all shareholders

D- The role of stakeholders to exercise corporate governance rules

E- Disclosure and transparency for all stakeholders

F- Board of directors responsibility towards governance rules

2- Dependent variable: accounting disclosure.

Sample characteristics according to demographic, occupation variables.

Table 1 shows that $68 \%$ of participants hold Master's degree which is the highest in educational qualification, while Ph.D. holders are $9.4 \%$ which is the least in participants education qualification. Highest rank is 
department head with $56.6 \%$ which is the highest in middle management while top management reached up to $14 \%$.
$32.1 \%$ of participants have 5-10 years of experience while accounting and other are the highest of majoring items by $16 \%$.

Table (1)

Participants, according to demographic, and occupation

\begin{tabular}{|c|c|c|c|}
\hline & Class & Frequency & $\%$ \\
\hline \multirow{3}{*}{ Education Qualification } & BA & 12 & 22.6 \\
\hline & MA & 36 & 68 \\
\hline & $\mathrm{PhD}$ & 5 & 9.4 \\
\hline \multirow{3}{*}{$\begin{array}{c}\text { Occupation } \\
\text { Level }\end{array}$} & Board of directors & 9 & 17 \\
\hline & Director & 14 & 26.4 \\
\hline & Dept. head & 30 & 56.6 \\
\hline \multirow{4}{*}{ No. of years } & Less than 5 & 8 & 15.1 \\
\hline & $5-10$ & 17 & 32.1 \\
\hline & $11-15$ & 15 & 28.3 \\
\hline & More than 15 & 13 & 24.5 \\
\hline \multirow{4}{*}{ Majoring/ Specialization } & Accounting & 16 & 30.2 \\
\hline & Financial and barking science & 6 & 11.3 \\
\hline & Management & 15 & 28.3 \\
\hline & Others & 16 & 30.2 \\
\hline Total & ------ & 53 & 100 \\
\hline
\end{tabular}

The stability of the study instrument was verified by calculating the internal consistency according to the Cronbach's Alpha equation. Table (2) shows the stability coefficients for the sub-indices and the overall measure. The stability coefficients for the whole governance was 0.84 and for disclosure (0.76) for the purposes of scientific research.

Table (2)

\begin{tabular}{|c|c|}
\hline Dimensions & $\mathrm{R}^{2}$ \\
\hline 1- Solid and effective of corporate governance rules & 0.69 \\
\hline 2- Shareholders and stakeholders protection elements & 0.69 \\
\hline 3- Equal and fair treatment of all shareholders & 0.74 \\
\hline 4- Stakeholders role in rules practicing methods & 0.78 \\
\hline 5- Disclosure and transparency for all stakeholders & 0.75 \\
\hline 6- Board of directors responsibilities towards corporate governance rules & 0.84 \\
\hline Gccounting disclosure importance & 0.76 \\
\hline
\end{tabular}

\section{Data analysis and results:}

The main question: what is the impact of governance rules implementing on accounting disclosure of insurance companies financial reports listed in Amman stock exchange?

To answer this question, means and standards deviation for the rules implementing extent by insurance companies listed in Amman stock exchange. 
Table (3)

Means SD for governance rules implementing extent by insurance companies listed on Amman Stock Exchange in descending

\begin{tabular}{|c|c|l|c|c|c|}
\hline Rank & No. & \multicolumn{1}{|c|}{ Dimension } & Mears & SD & Level \\
\hline 1 & 3 & Fair and equal treatment among all shareholders & 3.93 & 1.020 & High \\
\hline 2 & 4 & Stakeholders role in governance rules practicing methods & 3.85 & .900 & High \\
\hline 3 & 5 & Disclosure and transparency for all stakeholders & 3.76 & .846 & High \\
\hline 4 & 6 & Board of directors responsibility towards governance rules & 3.70 & 1.052 & High \\
\hline 5 & 2 & Shareholders and investors protection & 3.46 & 0.693 & Medium \\
\hline 6 & 1 & Solid and effective governance rules & 3.06 & .165 & Medium \\
\hline & & Governance as whole & 3.62 & 0.554 & \\
\hline
\end{tabular}

Table 3 shows that means are between 3.06-3.93, whereas, equal and fair treatment among all shareholders comes in first place (rank) with means of 3.93 while dimension solid and effective foundation for governance rule comes in the last place with means of 3.06 while instruments, as a whole, means is 3.62 .

There are several sub-questions stemmed from the main question. Their means and standard deviations are as follow:

1- What is the effect of solid and effective corporate governance foundation, on accounting disclosure in financial reports of insurance companies listed on Amman Stock Exchange?

Table (4)

Means and SD for dimensions items "solid and effective governance in describing order of means,

\begin{tabular}{|c|c|l|c|c|c|}
\hline rank & No. & \multicolumn{1}{|c|}{ Item } & means & SD & Level \\
\hline 1 & 1 & $\begin{array}{l}\text { There are clear legislation and laws that determine responsibilities with achieving } \\
\text { people's interest assurance (shareholders, employees... }\end{array}$ & 3.21 & 1.343 & Medium \\
\hline 2 & 2 & $\begin{array}{l}\text { Does the Jordanian companies law guarantee they right of shareholders ort beard of } \\
\text { directors voting }\end{array}$ & 3.04 & 1.261 & Medium \\
\hline 3 & 3 & $\begin{array}{l}\text { Complies listed in Amman stack exchange do disclosures that enable others to } \\
\text { obtain information periodically and regularly }\end{array}$ & 2.93 & 1.052 & Medium \\
\hline
\end{tabular}

2- What is the impact of implementing the rule "shareholders and investment protection" on accounting disclosure in financial reports of companies listed on Amman Stock Exchange?

Table (5)

Means and SD of items after the availability of shareholders and investor elements in descending order according to the means

\begin{tabular}{|c|c|l|c|c|c|}
\hline rank & No. & \multicolumn{1}{|c|}{ Item } & means & SD & Level \\
\hline 1 & 3 & Shareholders have the right to access any information disclosure in financial lists & 3.64 & .911 & medium \\
\hline 2 & 1 & There is facility in transfer share ownership among shareholders & 3.36 & 1.062 & medium \\
\hline 3 & 2 & $\begin{array}{l}\text { Shareholders participate in voting in board of directors meeting and major } \\
\text { processes it performs within the company that provides protection to shareholders } \\
\text { and investors }\end{array}$ & $\begin{array}{c}1.166 \\
.693\end{array}$ & 3.21 & medium \\
\hline
\end{tabular}

3- What is the impact of rule implementing (Equal and Fair treatment among all shareholders on accounting disclosures in financial reports of companies listed in Amman stock exchange?

Table (6)

Means and SD of items after the availability of equal and fair treatment factors among all shareholders in descending order according to means

\begin{tabular}{|c|c|c|c|c|c|}
\hline rank & No. & Item & means & SD & Level \\
\hline 1 & 3 & $\begin{array}{l}\text { Protection of shareholders minority rights against any illegal, exploitive } \\
\text { practices, with the presence of effective compensational means }\end{array}$ & 4.04 & 1.105 & High \\
\hline 2 & 3 & $\begin{array}{l}\text { The availability of effective compensation laws, mechanisms, and means to } \\
\text { shareholders protection }\end{array}$ & 3.93 & 1.303 & High \\
\hline 1 & 3 & Equality in of all shareholders is one of governance most important aspects & 3.82 & 1.307 & High \\
\hline & & Equal and fair treatment is present among all shareholders & 3.93 & 1.020 & \\
\hline
\end{tabular}


4- What is the impact of implementing the rule (the role of stakeholders) in control exercising on accounting disclosure in financial reports of insurance companies listed in Amman Stock Exchange?

Table (7)

Means and SD of items after the availability of stakeholder role elements in control exercising on accounting disclosure in financial reports in descending order according to means

\begin{tabular}{|c|c|c|c|c|c|}
\hline rank & No. & Item & means & SD & Level \\
\hline 1 & 3 & $\begin{array}{l}\text { The development of mechanisms and strategies so as to have all workers } \\
\text { participate in performance enhancement }\end{array}$ & 4.04 & .964 & High \\
\hline 2 & 1 & Shareholders duties are facilitated according to the rules of law & 3.89 & .875 & High \\
\hline \multirow[t]{2}{*}{3} & 2 & $\begin{array}{l}\text { the presence of effective mechanism and bylaws between the board of directors } \\
\text { and shareholders so as to provide company's sustainability and success }\end{array}$ & 3.61 & 1.343 & Medium \\
\hline & & The presence of shareholders role methods so as to exercise governance rules & 3.85 & 900 & \\
\hline
\end{tabular}

5-what is the impact of the rule implementing (the presence of disclosure and transparency to all shareholders) on accounting disclosure in financial reports of companies listed on Amman stock exchange?

Table (8)

Means and SD of items after the presence of disclosure and transparency factors to all shareholders in descending order according to the means

\begin{tabular}{|c|c|c|c|c|c|}
\hline rank & No. & 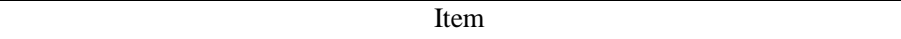 & means & SD & Level \\
\hline 1 & 2 & Doing disclosure sufficiently for all financial position factors without exception & 3.86 & 1.079 & high \\
\hline 1 & 2 & $\begin{array}{l}\text { Doing disclosure about company's internal control systems effectiveness and } \\
\text { competency extent is done }\end{array}$ & 3.86 & .932 & high \\
\hline \multirow[t]{2}{*}{3} & 3 & $\begin{array}{l}\text { doing shares ownerships disclosure about shares' ownership for all shareholders } \\
\text { with all shares kinds }\end{array}$ & 3.57 & 1.069 & medium \\
\hline & & The presence of disclosure and transparency for all shareholders & 3.76 & .846 & \\
\hline
\end{tabular}

6-what is the impact of the rule implementing (board member responsibility) in control practice over management, their role in accounting disclosure in financial reports of companies listed on Amman stock exchange?

Table (9)

Means and SD of board of directors' responsibility items, in descending order according to means

\begin{tabular}{|l|l|l|l|l|l|}
\hline rank & No. & Item & means & SD & Level \\
\hline 1 & 1 & The board abides by law and by-laws with other parties interest concern & 3.79 & 1.031 & High \\
\hline 2 & 2 & The board treats shareholders equally and fairly for every class of these & 3.68 & 1.090 & High \\
\hline 3 & 3 & $\begin{array}{l}\text { The board supervises and follows disclosure process and various communication } \\
\text { means }\end{array}$ & 3.64 & 1.193 & medium \\
\hline & The presence of board's responsibility factors towards governance rules & 3.70 & 1.052 & \\
\hline
\end{tabular}

Second question: what is the importance extent of accounting disclosure in insurance companies' financial reports?

To answer this question means and stand and deviations for accounting disclosures importance were computed as shown in table 10

Table (10)

\begin{tabular}{|c|c|l|c|c|c|}
\hline Rank & No. & \multicolumn{1}{|c|}{ Item } & means & SD & level \\
\hline 1 & 1 & $\begin{array}{l}\text { Accounting disclosure in financial reports leads to activate corporate governance } \\
\text { laws and mechanisms }\end{array}$ & 4.36 & .678 & High \\
\hline 2 & 2 & Company conducts disclosure as its responsibility towards Loral community & 4.29 & .937 & High \\
\hline 3 & 3 & $\begin{array}{l}\text { Abiding by legal requirements for accounting responsibilities support companies' } \\
\text { governance principles }\end{array}$ & 4.14 & 1.079 & High \\
\hline 3 & 4 & $\begin{array}{l}\text { Company utilizes its website to enhance disclosure, transparency and information } \\
\text { availability }\end{array}$ & 4.14 & 1.079 & high \\
\hline
\end{tabular}




\begin{tabular}{|c|c|c|c|c|c|}
\hline 4 & 5 & $\begin{array}{l}\text { Legislative and legal framework of accounting disclosure and corporate governance } \\
\text { contribute to support disclosure in companies }\end{array}$ & 3.79 & 1.228 & high \\
\hline \multirow[t]{2}{*}{5} & 6 & $\begin{array}{l}\text { Companies provide work procedures that are appropriate to disclosure policy } \\
\text { adopted by board of directors }\end{array}$ & 3.36 & 1.471 & medium \\
\hline & & The importance of accounting disclosure & 4.01 & .748 & \\
\hline
\end{tabular}

Table 10 shows that means are between3.36-4.36 whereas item (1) that states "accounting disclosure in financial lists lead to enacting corporate governance laws and mechanisms "in first place with means 4.36. While item (6) that states "company provides work procedures. Appropriate with board's policy for disclosure. "In the last place with means 3.36. While means for the entire dimension is 4.01 .

Analysis and Testing Study's Hypotheses

Table (11)

Regression analysis of the impact of applying the rules of governance on the accounting disclosure in insurance companies listed

\begin{tabular}{|c|c|c|c|c|c|c|c|}
\hline Independent variable & Beta & $\mathrm{T}$ value & $\begin{array}{l}\text { T Statically } \\
\text { significance }\end{array}$ & Correlation & Varieties & F value & $\begin{array}{l}\text { F Statically } \\
\text { significance }\end{array}$ \\
\hline $\begin{array}{l}\text { First Dimension: The presence of } \\
\text { solid and effective governance rules' } \\
\text { foundation. }\end{array}$ & -.234 & -1.509 & .146 & \multirow{6}{*}{.841} & \multirow{6}{*}{.708} & \multirow{6}{*}{8.482} & \\
\hline $\begin{array}{l}\text { Second Dimension: The presence of } \\
\text { shareholders and inventors } \\
\text { protection elements. }\end{array}$ & -.118 & -.855 & .402 & & & & \\
\hline $\begin{array}{l}\text { Third Dimension: The presence of } \\
\text { fair and equal treatment for all } \\
\text { shareholders. }\end{array}$ & 1.05 & 4.888 & .000 & & & & \\
\hline $\begin{array}{l}\text { Fourth Dimension: The presence of } \\
\text { shareholders role in governance rule } \\
\text { practice methods. }\end{array}$ & -.151 & -.636 & .531 & & & & \\
\hline $\begin{array}{l}\text { Fifth Dimension: The presence of } \\
\text { disclosure and transparency } \\
\text { elements to all shareholders. }\end{array}$ & -.170 & -.906 & .375 & & & & \\
\hline $\begin{array}{l}\text { Sixth Dimension: The presence of } \\
\text { boards' responsibilities factors } \\
\text { towards governance. }\end{array}$ & -.187 & -.774 & .447 & & & & \\
\hline
\end{tabular}

The table above shows the intercepted variation is 0.708 which means that independent variables (all six dimensions) have explained $7.8 \%$ of the difference in accounting disclosure importance. Also, it shows statically significant positive impact for the presence of the variable, the presence of equal and fair treatment among all shareholders in regard to accounting disclosure importance where its value is 4.888 with statically significance of 0.000 no statically significance of other dimensions.
Major hypothesis: there is a statistically significant impact at 0.05 for corporate governance implementing on accounting disclosure of insurance companies listed in Amman stock exchange.

To test this hypothesis, regression analysis of the impact of applying the rules of corporate governance on accounting disclosure of insurance companies listed in Amman stock exchange as it is shown in the table (11). 
Table (11-1)

\begin{tabular}{|c|c|c|c|}
\hline Independent variable & Beta & T Value & T Statically Significance \\
\hline Corporate governance solid and effective foundation & -.234 & -1.509 & 0.146 \\
\hline
\end{tabular}

Statistically significance at 0.05

Table 11-1 shows that $\mathrm{T}$ value is -1.509 with the statistical significance of .146 which indicates a negative impact of corporate governance solid and effective foundation on accounting disclosure in financial reports of insurance companies listed in Amman stock exchange.

Hypothesis two: there is a statistically significant impact at $\mathrm{a} \leq 0.05$ provides protection to shareholders and investors on accounting disclosure in financial lists of insurance companies listed on Amman stock exchange:

in order to be sure of this hypothesis accuracy regression analysis was conducted for "the impact of shareholders and investors" protection factors on accounting disclosure in financial reports of insurance companies listed in Amman stock exchange as it is shown in table 11-2

\begin{tabular}{|c|c|c|c|}
\hline \\
\hline Independent variable & Beta & T Value & T Statically Significance \\
\hline Shareholders and investors protection & -.118 & -.855 & 0,402 \\
\hline
\end{tabular}

Statistically significance at 0.05

Table 11-2 shows that the $\mathrm{T}$ - value is -0.855 with a statistical significance of 0.402 which indicates a negative impact of "shareholders and investors protection factors on accounting disclosure in a financial list of insurance companies listed in Amman Stock Exchange.

Hypotheses 3: there is the statistically significant impact at $\mathrm{a} \leq 0.05$ of the presences of equal and fair treatment among all shareholders on the accounting disclosure in the financial reports of insurance companies listed in Amman stock exchange.
In order to be sure of hypothesis accuracy regression analysis for the presence of equal and fair treatment among all shareholders on the accounting listed in Amman Stock Exchange.

In order to be sure of hypothesis accuracy regression analysis for the presence of equal and fair treatment factor to all shareholders on accounting disclosure in the financial report of insurance companies listed in Amman stock exchange as it is shown in table 11-3:

\begin{tabular}{|c|c|c|c|}
\hline Table $(11-3)$ \\
\begin{tabular}{|c|c|c|c|}
\hline Independent variable & Beta & T value & T Statically Significance \\
\hline Equal and fair treatment for all shareholders & 1.057 & 4.888 & .000 \\
\hline
\end{tabular}
\end{tabular}

Statistical function at significance level (0.05)

Table 11-3 shows that $T$. value is 4.888 with statistically significant at .000 which indicates the presence of positive impact of equal and fair treatment between all shareholders on accounting disclosure in financial reports of insurance companies listed in Amman stock exchange.

Hypothesis 4: There is a statistically significant impact at $\mathrm{a} \leq$ 0.05 of the role of stakeholders in practicing governance rules on accounting disclosure in financial reports of insurance companies listed on Amman Stock Exchange.

To be sure of this hypothesis accuracy regression analysis of stakeholders practicing governance rules methods on accounting disclosure in financial lists of insurance companies listed in Amman stock exchange as it is shown in table 11-4:

Table (11-4)

\begin{tabular}{|c|c|c|c|}
\hline Independent Variable & Beta & T value & $\begin{array}{c}\text { T statistically } \\
\text { significance }\end{array}$ \\
\hline $\begin{array}{c}\text { Stakeholders role in the } \\
\text { particing of governance rules } \\
\text { methods }\end{array}$ & -0.151 & -0.636 & 0.531 \\
\hline
\end{tabular}

Statistical function at significance level (0.05)

Table 11-4 shows $\mathrm{T}$ value is 0.636 with statistically significance .53. This indicates a negative impact of stakeholders role in governance practicing methods, on accounting disclosure in financial lists of insurance companies listed in Amman stock exchange.
Hypothesis 5: There is a statistically significant impact at a $\leq 0.05$ for disclosure and transparency to all stockholders on accounting disclosure and transparency to all stockholders on accounting disclosure in financial reports of insurance companies listed in Amman Stock Exchange. 
To verify this hypothesis, a regression analysis was used to calculate the effect of the availability of disclosure and transparency components for all stakeholders on accounting disclosure in the financial statements of insurance companies listed on the Amman Stock Exchange, as shown in the following table:

Table (11-5)

A regression analysis of the effect of disclosure and transparency factors for all stakeholders on accounting disclosure in the financial reports of insurance companies listed on the Amman Stock Exchange.

\begin{tabular}{|c|c|c|c|}
\hline Independent Variable & Beta & T value & $\begin{array}{c}\text { T statistically } \\
\text { significance }\end{array}$ \\
\hline $\begin{array}{c}\text { Disclosure and transparency } \\
\text { to all stakeholders }\end{array}$ & 0.170 & -0.906 & 0.375 \\
\hline
\end{tabular}

Statistical function at significance level (0.05)

Table (11-5) shows that the value of "T" -.906 in statistical terms (3.75) indicates that there is a negative impact of the availability of disclosure and transparency elements for all stakeholders on the accounting disclosure in the financial reports of insurance companies listed on the Amman Stock Exchange, This hypothesis is rejected.

The sixth hypothesis: There is a significant effect at the level of significance (a 0.05) to provide the elements of the responsibilities of the Board of Directors on accounting disclosure in the financial reports of insurance companies listed on the Amman Stock Exchange.

To verify this hypothesis, a regression analysis was used to calculate the effect of the availability of the Board of Directors' liability on accounting disclosure in the financial statements of insurance companies listed on the Amman Stock Exchange, as shown in the following table:

Table (11-6)

A regression analysis of the impact of the Board of Directors' responsibilities on accounting disclosure in the financial reports of insurance companies listed on the Amman Stock Exchange.

\begin{tabular}{|c|c|c|c|}
\hline Independent Variable & Beta & T value & $\begin{array}{c}\text { T statistically } \\
\text { significance }\end{array}$ \\
\hline $\begin{array}{c}\text { Elements of the } \\
\text { responsibilities of the Board } \\
\text { of Directors }\end{array}$ & -187 & -774 & 447 \\
\hline
\end{tabular}

Statistical function at significance level (0.05)

Table (6-11) shows that the value of "T" - 7.74 in statistical terms (447) indicates that there is a negative impact on the availability of the responsibilities of the Board of Directors on the accounting disclosure in the financial statements of insurance companies listed on the Amman Stock Exchange. Reject this hypothesis.

\section{CONCLUSIONS AND RECOMMENDATIONS RESULTS}

In the light of the theoretical and practical analysis of the study which is conducted on insurance companies listed on Amman Stock Exchange, the following results were revealed:

The analyses show that although there is a strong and effective basis for the rules of governance applied to insurance companies listed on the Amman Stock Exchange, the rules of governance still need to be further developed and followed up with the continuous updates related to these rules.

Some laws are in place to protect shareholders and investors in insurance companies in the Amman Stock Exchange, which affects the volume of investments and investors' desire to invest in companies listed on the Amman Stock Exchange.
The results also showed that there is an application of the elements of fair and equal treatment among all shareholders in insurance companies listed on the Amman Stock Exchange, which reflects positively on the level of satisfaction to the current shareholders, in addition to attracting investments.

The results showed that there is an activation of the role of stakeholders in practicing the methods of the rules of governance to an insufficient degree in the insurance companies listed in Amman Financial Market, which requires enacting of new laws and regulations that lead to activating their role in the exercise of the rules of governance. Furthermore, the results indicated the lack of sufficient elements for disclosure and transparency for all stakeholders Insurance companies listed on Amman Stock Exchange, which affects the validity of decisions of investors, shareholders and capital owners in making their investment decisions.

The results pointed out to the limited role of the board of directors in the selection of executives of insurance companies listed on Amman Stock Exchange, which directly affects decision-making, which leads to weakens their ability to accountability and follow-up to executives.

The existence of a Corporate Governance Guide is essential to the performance of all companies listed on the Amman Stock Exchange. 
Maintaining the independence of the financial market and ensuring it does not affect its decisions contributing to enhancing confidence in it and thus providing information in a fair and equal manner to all.

\section{RECOMMENDATIONS}

Based on the results of the study, researchers recommend the following:

1. The need to exert more efforts and follow-up that relate to the implementation of the rules of governance in the insurance companies listed in the Amman Financial Market in order to develop awareness and the role of investment in society.

2. Work on updating the legal and regulatory frameworks that provide the necessary protection to investors, which leads to the development of investment and maximize the role of companies in this field.

3 . The need to give the powers to and the role of wider stakeholders in the exercise of participation role on the management, which contributes to support and encourage investors.

4. Increase the level of disclosure and transparency in financial reports and make it available to all stakeholders to give shareholders and investors the safety for their money.

5 . The necessity of increasing the effectiveness of the role of the Board of Directors in selecting executive directors and exercising their role in applying laws and regulations.

6. The need to maintain the independence of the Amman Financial Market, ensure that its decisions are not affected by listed companies or member companies, as well as provide information center for investors and shareholders in the financial market, which provides all information on all listed companies so that investors can benefit from them in rationalizing their investment decisions.

7. Promote the culture of practicing governance by holding training programs that reflect the concepts and culture of governance applications.

8. The need to conduct further studies and research on the application of good governance and practice, and its role in preventing financial failure of companies.

\section{REFERENCES}

[1] Abu Hama, M. 2009 "The impact of governance rules implementing on accounting disclosure of financial reports quality: an Empirical study over companies listed on Palestinian securities market" Master thesis, Islamic University, Accounting, and Finance Division, Ghaza.

[2] Sartawi, A. 2015, "The impact of institutional governance on companies listed in financial markets in Gulf States Cooperation Council (GSCC)" Business Management Jordanian magazine, Folder 11, No.11

[3] Al- Sharati, s. 2010, "The disclosure of companies governance in financial reports and its determinants", Master thesis, AlYarmouk University, Accounting division, Jordan.

[4] Al- Shunnaq, s. 2013, "The disclosure of companies governance and the financial performance: an empirical study over the Jordanian commercial banks" Master thesis, AlYarmouk University, Accounting division, Jordan.

[5] Al- Mustafa, M. 2012 "The impact of governance on the profit management practices: the empirical study on the industrial companies listed in Amman stock exchange", Master thesis, Al- Yarmouk University, Accounting division, Jordan.

[6] Al- Manaseer, O. 2013, "The impact of governance rules implementing on the performance of Shareholding service companies" Master thesis, The Hashemite University, Accounting division, Al- Zarqa'a, Jordan.

[7] Mousa, S.; Khalidi, F. 2012, "The impact of governance rules implementing on the accounting disclosure and financial reports quality" Forum of companies governance as a strategy to reduce the financial and administrative corruption, Mohamed Khider University, Department of financial sciences, 07-06 May, Pages 3-

[8] Core. J, Guay.W and Rusticus.T (2005), "Does Weak Governance Cause Weak Stock Returns? An Examination of Firm Operating Performance and Investors' Expectations", Social science Research Network.

[9] Madhani.M (2015),"The Impact of Board Characteristics On Corporate Governance and Disclosure Practices Of Firms Listed In Indian Stock Exchange", The IUP Journal of Corporate Governance, Vol.(35), No.(4). PP.14-46.

[10] Marashdeh.Z (2014),"The Effect of Corporate Governance on Firm Performance in Jordan", A thesis submitted in partial fulfillment for the requirements for the degree of Ph.D., at the University of Central Lancashire.

[11] AL-Moataz.E and Hussainey.K(2013),"Determinants of Corporate Governance Disclosure In Saudi Corporations", JKAU: Econ.\& Admn., vol.(27), NO.(2), PP:411-430.

[12] Amman Financial Market, (www.ase.com.jo/ar), entered 19/11/2016.

[13] Jordan Insurance Federation 2016 (www.joif.org), entered $2 / 11 / 2016$. 